\title{
Polymorphism analysis of the CTLA-4 gene in paracoccidioidomycosis patients
}

\author{
Viviane F Lozano', Tulio C Lins ${ }^{1,2}$, Marcus M Teixeira ${ }^{3}$, Rodrigo G Vieira ${ }^{2}$, \\ Maria Heloisa SL Blotta ${ }^{4}$, Alfredo M Goes ${ }^{5}$, Izabel Cristina R Silva', \\ Rinaldo W Pereira ${ }^{2}$, Anamelia L Bocca ${ }^{1,3 /+}$, Maria Sueli S Felipe ${ }^{1,3}$ \\ ${ }^{1}$ Faculdade de Medicina ${ }^{3}$ Instituto de Ciências Biológicas, Universidade de Brasília, Brasília, DF, Brasil \\ ${ }^{2}$ Programa de Pós-Graduação em Ciências Genômicas e Biotecnologia, Universidade Católica de Brasília, Brasília, DF, Brasil \\ ${ }^{4}$ Faculdade de Ciências Médicas, Universidade Estadual de Campinas, Campinas, SP, Brasil \\ ${ }^{5}$ Instituto de Ciências Biológicas, Universidade Federal de Minas Gerais, Belo Horizonte, MG, Brasil
}

\begin{abstract}
The CTLA-4 protein is expressed in activated T cells and plays an essential role in the immune response through its regulatory effect on T cell activation. Polymorphisms of the CTLA-4 gene have been correlated with autoimmune, neoplastic and infectious illnesses. This work aimed to verify possible associations between single nucleotide polymorphisms (SNPS) in CTLA-4, -318C/T in the promoter and $+49 A / G$ in exon 1 and paracoccidioidomycosis (PCM) caused by Paracoccidioides brasiliensis. For this purpose, 66 chronic form PCM patients and 76 healthy controls had their allele, genotype and haplotype frequencies determined. The genetic admixture structure of the patients and controls was evaluated to eliminate ancestral bias. The comparison of frequencies indicated no significant differences between patients and controls that could link the SNPs to PCM. Groups were admixture matched with no difference observed in population ancestry inference, indicating that the absence of association between CTLA-4 polymorphisms and PCM could not be attributed to ancestral bias. This study showed that there was no association between the CTLA-4 SNPS -318 and +49 and the resistance or susceptibility to PCM.
\end{abstract}

Key words: admixture - Brazilian population - haplotypes - Paracoccidioides brasiliensis - PCM - single nucleotide polymorphism

CTLA-4 is an inhibitory receptor expressed transiently on activated $\mathrm{CD} 4^{+}$and $\mathrm{CD} 8^{+} \mathrm{T}$ lymphocytes and constitutively on $\mathrm{CD} 44^{+} \mathrm{CD} 25^{+} \mathrm{T}$ regulatory lymphocytes (Treg) and a few non-lymphoid cells (Balbi et al. 2007). CTLA-4, a receptor structurally homologous to CD28, acts as a negative regulator of $\mathrm{T}$ cell responses by interacting with B7 molecules on antigen presenting cells; in contrast, a costimulatory signal is evoked by CD28-B7 interaction (Ling et al. 2001, Butty et al. 2007). Antibody-mediated blockage of CTLA-4 in vivo has been demonstrated to upregulate the immune response in murine models of infection, autoimmune disease, tumour immunity, allergy and vaccination (Martins et al. 2004, Thio et al. 2004). The CTLA-4 gene has been mapped to human chromosome 2q33 (Dariavach et al. 1988) and consists of four exons that encode a leader sequence and extracellular, transmembrane and cytoplasmic domains (Harper et al. 1991, Ling et al. 2001). Two main human CTLA-4 transcripts have been detected: a full-length isoform and a soluble form lacking exon 3 (Harper et al. 1991, Ueda et al. 2003, Gough et al. 2005). Various single nucleotide polymorphisms (SNPs) in the CTLA-4 gene have been implicated in susceptibility to autoim-

Financial support: CAPES, CNPq, FAP-DF

+ Corresponding author: albocca@unb.br

Received 10 September 2010

Accepted 10 January 2011 mune disorders including Graves disease (Yanagawa et al. 1995), type 1 diabetes mellitus (Nisticò et al. 1996), celiac disease (Holopainen et al. 2004, van Belzen et al. 2004), Addison's disease (Blomhoff et al. 2004), autoimmune thyroid disease (Tomer et al. 2001, Zaletel et al. 2006), systemic lupus erythematosus (Barreto et al. 2004, Lee et al. 2005) and rheumatoid arthritis (Han et al. 2005). Other studies also correlated polymorphisms in the CTLA-4 gene with neoplastic diseases, such as breast cancer (Ghaderi et al. 2004), and infections, such as hepatitis B (Thio et al. 2004).

Paracoccidioidomycosis (PCM) is a systemic mycosis caused by the thermo-dimorphic fungus Paracoccidioides brasiliensis (Restrepo 1985). It occurs in two different forms, the infection (asymptomatic) and the disease (symptomatic); the latter can be subdivided into acute (juvenile form) and chronic (adult form) (Franco 1987).

Human and experimental PCM evoke a great variety of immune responses with a large range of clinical manifestations, which depend on the degree of suppression of cellular immunity (Bocca et al. 1998, Campanelli et al. 2003, Cavassani et al. 2006). An imbalance in cytokine production, apoptosis-induced cell death and high levels of Fas-L and CTLA-4 expression in T cells seem to be involved in $\mathrm{T}$ cell unresponsiveness. There is increased expression of CTLA-4 protein in Treg cells of PCM patients relative to control groups. In addition, Treg cells are present in the lesions and peripheral blood from patients with the chronic form of PCM, suggesting local and systemic regulation of the immune response in this illness (Cavassani et al. 2006). 
This study aimed to verify the association between CTLA-4 gene polymorphisms and the risk of developing PCM. Two polymorphisms that cause changes in CTLA-4 expression were the target of our study: the exon $1+49 \mathrm{~A} / \mathrm{G}$ polymorphism, which causes a substitution of alanine for threonine in the 17th position of the precursor protein (a substitution in the signal peptide) (Nisticò et al. 1996), and the $-318 \mathrm{C} / \mathrm{T}$ polymorphism in the promoter region (Deichmann et al. 1996). Individuals carrying the A allele of SNP +49 or the T allele of SNP -318 have increased expression of CTLA-4 on the cell surface (Ligers et al. 2001). The individual biogeographical ancestry estimate was taken for both patient and control groups, as a means to minimize potential spurious results attributable to the admixed nature of the population sample studied.

\section{PATIENTS, MATERIALS AND METHODS}

Human blood samples - Samples from 66 PCM patients diagnosed with the chronic form (aged 13-70, nonrelated males and females) comprised the test group and were collected from the southeastern and central-west Brazilian regions, both considered endemic areas. The control group was made up of 76 volunteers (aged 9-75, non-related males and females) from the central-west region, none of whom had ever contracted PCM. This study was approved by the ethical committee of the Brasília University and informed consent was obtained from each subject or their parent or guardian before sampling.

Genomic DNA extraction - Genomic DNA was extracted from peripheral blood cells using the DNA extraction kit GeneCatcher ${ }^{\odot}$ gDNA Blood Kits (Invitrogen). The extracted DNA was quantified using a GeneQuant ${ }^{\circ}$ Pro spectrophotometer (GE Healthcare).

Polymerase chain reaction (PCR) amplification and SNP genotyping - The region containing the SNPs $(-318 \mathrm{C} / \mathrm{T}$ in the promoter and $+49 \mathrm{~A} / \mathrm{G}$ in exon 1) was amplified by PCR using the following primer pair designed based on sequences retrieved from GenBank (accession M74363): P1 forward (5'AGGCTCAGAAGTTAGCAGCCT 3') and P1 reverse (5'CCCTGGAATACAGAGCCAGC 3'). PCRs were carried out in reactions containing each primer at $0.1 \mu \mathrm{M}, 10-50 \mathrm{ng}$ of DNA, $25 \mu \mathrm{L}$ of FideliTaq ${ }^{\circ}$ (USB Corporation) and water to a total volume of $50 \mu \mathrm{L}$. The PCR program was as follows: initial denaturation at $95^{\circ} \mathrm{C}$ for $1 \mathrm{~min}, 28$ cycles comprised of $20 \mathrm{sec}$ at $95^{\circ} \mathrm{C}, 1 \mathrm{~min}$ annealing at $62^{\circ} \mathrm{C}$ and extension for $1 \mathrm{~min}$ at $72^{\circ} \mathrm{C}$, and a final extension for $5 \mathrm{~min}$ at $72^{\circ} \mathrm{C}$. The amplified DNA was resolved by electrophoresis in a $1 \%$ agarose gel, revealing fragments of approximately $700 \mathrm{bp}$, as expected. Amplicons were purified with the GFX ${ }^{\circ}$ PCR DNA and Gel Band Purification Kit (GE Healthcare) and then submitted for automatic sequencing on a MegaBACE ${ }^{\mathcal{O}} 1,000$ (GE Healthcare). The determination of the bases located on the -318 and +49 positions of CTLA-4 was done using individual electropherogram analysis.

$P C R$ reactions for ancestry markers - An optimised PCR was used to co-amplify two multiplex panels of ancestry informative markers in DNA samples from patients and controls. Afterwards, the PCR-amplified products were purified in an enzymatic treatment with exonuclease I (Exo I) and shrimp alkaline phosphatase to eliminate non-incorporated dNTPs and primers. Finally, the minisequencing reaction was performed using the SNaPshot ${ }^{\circledR}$ Multiplex minisequencing kit reaction mix (Applied Biosystems) and the products of the $\mathrm{SNaPshot}{ }^{\mathbb{B}}$ reaction were analysed on an ABI 3130 XL Genetic Analyser (Applied Biosystems) in an ABI 3,700 POP $-6^{\circ}$ polymer. Genotypes were determined using GeneScan Analysis Software, version 3.7 (Applied Biosystems) and Genotyper version 3.7 (Applied Biosystems). A detailed, optimized multiplex, singlebase extension protocol, with reagent concentrations and PCR thermocycling conditions, was described elsewhere (Lins et al. 2007, 2010a).

Statistical analysis - Allele and genotype frequencies were obtained through electropherogram analysis by direct counting. Comparisons of genotypes and alleles between PCM patients and the control group were performed by using $\chi^{2}$ test calculated on $2 \times 2$ or $2 \times 3$ contingency tables and the odds ratio and $95 \%$ confidence intervals were calculated as measurements of the strength of association, both using the SPSS Data Editor software (release 17.0). Deviation from the Hardy-Weinberg Equilibrium (HWE) was tested with Pearson's $\chi^{2}$ test using the Finneti software (http://ihg2.helmholtzmuenchen.de/cgi-bin/hw/hwal.pl). The estimation of haplotypes, their frequencies and linkage disequilibrium (LD) between SNPs -318 and +49 were calculated using the expectative maximization algorithm on the Haploview software (Barrett et al. 2005). The association between the haplotypes of patients and controls was verified with the same software, using a $\chi^{2}$ test with statistical significance defined by $\mathrm{p}<0.05$.

Population structure analysis - Samples from PCM patients and controls were evaluated for population structure to avoid spurious results due to population admixture. Sixteen ancestry informative markers with large differences in allelic frequency were previously selected to estimate genetic admixture (Moreno Lima et al. 2007). Genotype data from three ethnic parental populations were used to adjust inference in admixed population: Sub-Saharan African (120 individuals), Amerindian (69 individuals) and European-American (78 individuals) (Smith et al. 2004, Lins et al. 2010a). The evaluation of population structure was performed using the Structure 2.1 software by means of Bayesian inference (Pritchard et al. 2000). The program parameters were set to 75,000 for the length of burn-in period and 35,000 Markov Chain Monte Carlo method extra repetitions, with $\mathrm{K}$ varying from 1-10. The model of admixture with correlated allele frequencies among populations was used.

\section{RESULTS}

Analysis of SNPS $-318 C / T$ and $+49 A / G$ - The CTLA-4 $-318 \mathrm{C} / \mathrm{T}$ allele and genotype frequency distributions in PCM patients $(n=66)$ and controls $(n=76)$ are reported in Table I. Both groups had equivalent distributions with the most frequent genotype being $\mathrm{CC}$, followed by 
TABLE I

Genotype and allelic distribution with their respective frequencies to -318 promoter position of CTLA-4 in paracoccidioidomycosis patients and controls

\begin{tabular}{|c|c|c|c|c|c|c|c|c|c|}
\hline & & $\begin{array}{l}\text { Patients } \\
(\mathrm{n}=66)\end{array}$ & & & $\begin{array}{l}\text { Controls } \\
(\mathrm{n}=76)\end{array}$ & & & & \\
\hline-318 position & $\mathrm{n}$ & $\begin{array}{l}\mathrm{f} 1 \\
(\%)\end{array}$ & $\begin{array}{l}\mathrm{f} 2 \\
(\%)\end{array}$ & $\mathrm{n}$ & $\begin{array}{l}\mathrm{f} 1 \\
(\%)\end{array}$ & $\begin{array}{l}\mathrm{f} 2 \\
(\%)\end{array}$ & $\mathrm{P}$ & OR & $95 \% \mathrm{CI}$ \\
\hline \multicolumn{10}{|l|}{ Genotypes } \\
\hline $\mathrm{CC}$ & 57 & 86 & 91 & 72 & 95 & 91 & 0.08 & 0.35 & $0.10-1.20$ \\
\hline $\mathrm{CT}$ & 9 & 14 & 9 & 4 & 5 & 9 & 0.08 & 2.84 & $0.83-9.71$ \\
\hline TT & 0 & 0 & 0 & 0 & 0 & 0 & - & - & - \\
\hline \multirow[t]{2}{*}{ HWE (p) } & - & 0.55 & - & - & 0.81 & - & - & - & - \\
\hline & & $\begin{array}{c}\text { Patients } \\
(2 \mathrm{n}=132) \\
\mathrm{n} / \mathrm{f}(\%)\end{array}$ & & & $\begin{array}{c}\text { Controls } \\
(2 \mathrm{n}=152) \\
\mathrm{n} / \mathrm{f}(\%)\end{array}$ & & $\mathrm{p}$ & OR & $95 \%$ CI \\
\hline \multicolumn{10}{|l|}{ Alleles } \\
\hline $\mathrm{C}$ & & $123 / 93$ & & & $148 / 97$ & & 0.09 & 0.37 & $0.11-1.23$ \\
\hline $\mathrm{T}$ & & 9/7 & & & $4 / 3$ & & 0.09 & 2.71 & $0.81-9.00$ \\
\hline
\end{tabular}

CI: confidence interval; f: frequency; f1: observed frequency; f2: expected frequency; $n$ : individuals number; OR: odds ratio; : p value; HWE: Hardy-Weinberg Equilibrium.

CT. The TT genotype was not observed in this sample in either group. The patient and control genotype frequencies were not significantly different $(p>0.05)$. No deviation from the HWE was observed for genotype frequencies in patients or controls. PCM patients and controls had similar allelic frequencies. The $\mathrm{C}$ allele was more frequent than the $\mathrm{T}$ allele in both patients and controls, without any significant difference in occurrence between the groups $(p>0.05)$.

The distribution of the $\mathrm{A}$ and $\mathrm{G}$ alleles and genotypes (AA, AG and GG) at position +49 in exon 1 of the CTLA-4 gene in PCM patients and controls is reported in Table II. The AA and AG genotypes were more prevalent than the GG genotype, with no significant difference in frequencies between the groups. No deviation from the HWE was observed for genotype frequencies in patients or controls. Consequently, PCM patients and controls had similar frequencies of each allele. The A allele was more frequent than $\mathrm{G}$ allele in both patients and controls, without any significant difference in occurrence between the groups $(\mathrm{p}>0.05)$.

Haplotype association between the $-318 C / T$ and $+49 A / G$ SNPS - The haplotypes of PCM patients and controls, as well as their respective frequencies, were estimated by the Haploview software, which enables the assessment of LD patterns between SNPs by means of a frequency deviation (D' value) (Barrett et al. 2005). Three haplotypes were identified in patients and controls by the allelic association between SNPs -318 and +49: CA, CG and TA. The haplotype distribution and respective frequencies in patients and controls are listed on Table III. LD was observed between SNPs (i.e., observed haplotype frequencies differed from what was expected under the LD hypothesis) and no significant difference was observed between haplotype frequencies of patients and controls.

Ancestry background in patients and controls - Individual ancestry estimates in the patient and control groups were estimated by Bayesian inference using sample data from three parental populations. The ancestry contribution of individuals was grouped into European, African and Amerindian clusters. Results show that patient and control groups respectively had background estimates of $72 \%$ and $77 \%$ European, $13 \%$ African in both groups and $15 \%$ and $10 \%$ Amerindian. No significant difference was observed using tests of homogeneity of means and variances $(p=0.499$ and $p=0.992$, respectively), confirming the admixture-matched contribution of ancestries for the two groups (Figure).

\section{DISCUSSION}

The goal of this work was to verify whether the $-318 \mathrm{C} / \mathrm{T}$ and $+49 \mathrm{~A} / \mathrm{G}$ SNPs, which are known to be associated with at CTLA-4 gene expression, were related to PCM susceptibility. No statistically significant connections between any of the investigated alleles and genotypes of the $C T$ $L A-4$ gene and PCM could be established by comparison of their frequencies in chronic patients and controls.

Experiments with T cells by Wang et al. (2002) showed that the $-318 \mathrm{~T}$ allele was associated with higher promoter activity and, therefore, increased gene expression and had a stronger negative regulatory effect on $\mathrm{T}$ 
TABLE II

Genotype and allelic distribution with their respective frequencies to +49 exon 1 position of CTLA-4 in paracoccidioidomycosis patients and controls

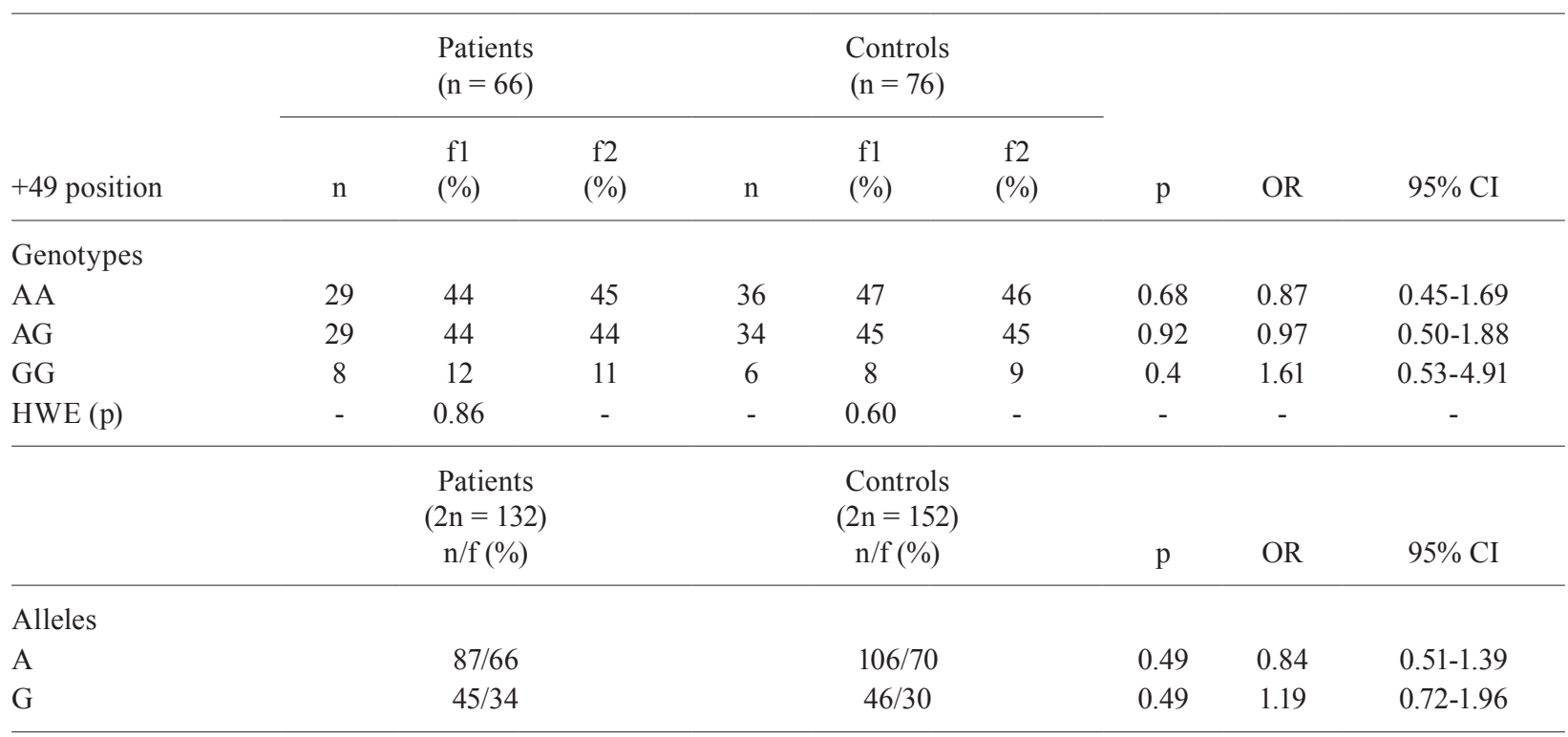

CI: confidence interval; f: frequency; f1: observed frequency; f2: expected frequency; $n$ : individuals number: OR: odds ratio; p: p value; HWE: Hardy-Weinberg Equilibrium.

TABLE III

Haplotype characterization and their respective frequencies in paracoccidioidomycosis patients and controls groups by Haploview software

\begin{tabular}{lccc}
\hline & $\begin{array}{c}\text { Patients } \\
(\mathrm{n}=66) \\
\mathrm{f}\end{array}$ & $\begin{array}{c}\text { Controls } \\
(\mathrm{n}=76)\end{array}$ & \\
Haplotype & $\begin{array}{c}\mathrm{f} \\
(\%)\end{array}$ & $\mathrm{p})$ & \\
\hline CA & 57.4 & 67.1 & 0.08 \\
CG & 36.5 & 30.3 & 0.25 \\
TA & 6.1 & 2.6 & 0.14 \\
\hline
\end{tabular}

observed and expected frequencies deviation $=1$; f: frequency; p: $p$ value.

cells by CTLA-4. Recent studies demonstrated that the SNP at position +49 of exon 1 also influences $T$ cell activation, affecting the inhibition of this process by CTLA- 4 , as the $+49 \mathrm{G}$ allele resulted in lower protein expression and, therefore, more pronounced proliferation of T cells (Kouki et al. 2000). Some autoimmune diseases have been correlated with this polymorphism, such as rheumatoid arthritis (Han et al. 2005), type 1 diabetes (Nisticò et al. 1996) and autoimmune thyroid disease (Tomer et al. 2001, Zaletel et al. 2006).

As reported before, PCM patients present with higher levels of CTLA-4 expression than healthy controls, which was associated with the immunosuppression observed during the disease. In addition, $\mathrm{T}$ cells recovered

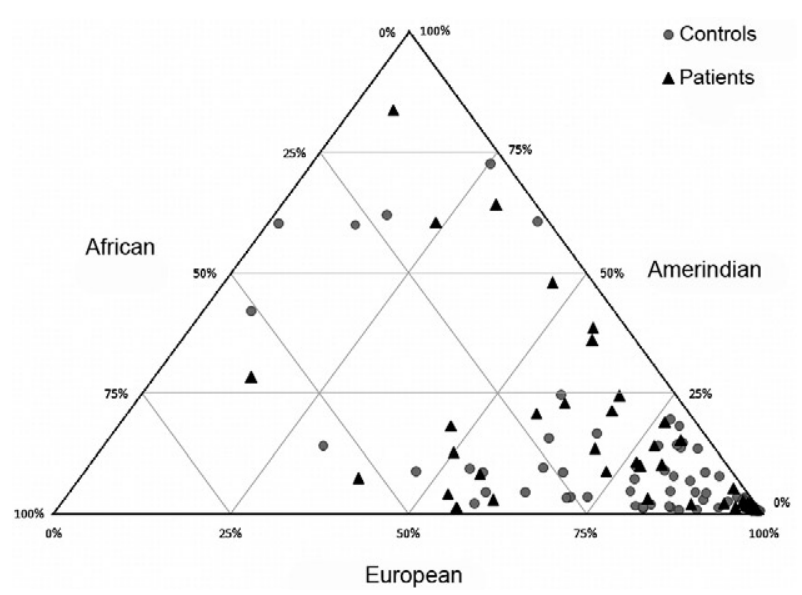

Triangle plot of individual ancestry estimates. Each of the three axes range from $0-100 \%$ at the vertices therefore assigning one population to another. The individual ancestry estimates is given by the distance of an individual to one of the triangle axis, into which paracoccidioidomycosis patients (black triangle) and controls (gray circles) were classified. European ancestry predominates in both admixturematched groups.

from blood and tissue lesions of chronic patients that had more CTLA-4 suggest that the immune response to the fungus is regulated at both the local and systemic levels (Campanelli et al. 2003).

Currently, there are few reports on CTLA-4 polymorphisms in the context of infection. A report by Thio et al. (2004) suggested that the $+49 \mathrm{G}$ allele, alone or linked to SNP $-1722 \mathrm{C}$, could be related to recovery after hepati- 
tis $\mathrm{B}$ virus infection by changing the pattern of negative regulation of the immune response caused by CTLA- 4 . The $+49 \mathrm{G}$ allele was detected more often in individuals who recover from hepatitis B infection, indicating that it improves the response to that infectious agent. These data are consistent with a report by Kouki et al. (2000), in which $+49 \mathrm{G}$ reduces CTLA- 4 expression and thus enhances the immune response. Recently, Su et al. (2007) investigated CTLA-4 polymorphisms and their relation to squamous cell carcinoma. The $-318 \mathrm{~T}$ allele was more often found in women infected by the human papilloma virus than in healthy women, which led them to postulate that this SNP could be implicated in the persistence of the virus, which causes cervical carcinoma. These studies confirm the work by Wang et al. (2002), which showed an association between the $-318 \mathrm{~T}$ allele and increased protein expression, leading to suppression of the immune response.

In our study, we determined the prevalence of the $-318 \mathrm{C}$ allele, presumably associated with a more effective response, in both patient and control groups, leading us to the conclusion that this SNP is unlikely to affect the response to PCM. However, previous studies have observed the existence of linkage between the -318 and +49 SNPs, suggesting that some haplotypes derived from the combination of these SNPs could be involved in susceptibility to diseases for which no single locus association was observed (Kristiansen et al. 2000, Ligers et al. 2001). Therefore, on observing the existence of a LD between the studied SNPs (D' = 1.00), we wanted to test the hypothesis that haplotype frequencies differed between patient and control groups. Still, no significant difference was found.

Polymorphisms in other genes that play a role in the immune response, such as cytokines, have been correlated with PCM. These include polymorphisms in IL-10 $(-1082 \mathrm{G} / \mathrm{A})$ and TNF- $\alpha(-308 \mathrm{G} / \mathrm{A})$ in PCM patients and controls (Bozzi et al. 2006). It was found that the IL-10 $-1082 \mathrm{G}$ allele, when homozygous, could be associated with an increased risk of contracting the illness. No such correlation was found for the polymorphism in TNF- $\alpha$, which was found in higher levels in the serum of PCM patients (Silva \& Figueiredo 1991).

Although some studies have been published concerning the influence of CTLA-4 on PCM (Bozzi et al. 2004, Cavassani et al. 2006), this study is the first to assess the association of polymorphisms and the fungal illness. Notably, population and individual genetic structure analysis was carried out on the patient and control groups. Association studies must include ancestry analysis to eliminate the possibility of spurious associations due to the genetic background of the sample (Lins et al. 2010b). In our study, European ancestry prevailed in both control and patient groups and the means and variances of population admixture were found to be statistically homogeneous. This result confirms that our study had consistent groups in terms of their admixture pattern and that the absence of a correlation between PCM and the CTLA-4 polymorphisms was not due to ancestral bias (Rosenberg \& Nordborg 2006).
Genotype and allele frequency values for the two $C T$ LA-4 SNPs analysed in this study were similar to those reported by Guzman et al. (2005). Those authors determined the frequency of polymorphisms in the CD28, ICOS and CTLA-4 genes (in the latter, polymorphisms in the -318 and +49 positions) in three ethnic groups of healthy Southeastern Brazilians (white, mulatto and black). Genotype and allele frequencies found in these ethnic groups were similar to those reported here for patients and controls, further corroborating our results.

More work needs to be done to conclusively prove that there is no connection between CTLA-4 and PCM patients. The limitation of sample size is an important issue, particularly when this study is compared to whole genome association studies conducted with thousands of cases and controls. Nevertheless, we believe that our results provide important information about susceptibility to PMC; specifically, if CTLA-4 does play a role in $\mathrm{PMC}$, then its effect is not strong enough to be detected at the statistical power allowed by our sample size. Alternatively, responsiveness to PCM and human susceptibilities to other fungal diseases, might be controlled by a huge number of genetic variants, each with a small effect on the trait (Carvalho et al. 2010). In this case, the sample size, even at whole genome association dimensions, may only be effective for identifying rare variants with larger effects (Goldstein 2009).

In summary, this work demonstrated that the SNPs at positions -318 and +49 of the $C T L A-4$ gene were not related to resistance or susceptibility to PCM in the present admixture-matched sample. In view of the complexity of the inflammatory process caused by PCM, we cannot exclude the possibility that polymorphisms in other genes that regulate the immune response could be related to the clinical outcome of the infection. Given the importance of the signalling molecules produced over the course of infection, the effects of rare variants of other genes must be investigated. Of particular interest are those genes that are responsible for signal transduction events in the cells that interact with the fungus and those that encode cytokines and other proteins that are central to cell activation and regulation of the host response. The results of this and future work will contribute to the knowledge base for meta-analyses on the association between CTLA-4 polymorphisms and immune responses to chronic infections.

\section{ACKNOWLEDGEMENTS}

To Professor Tarcília Aparecida da Silva, for her support to the project, to Hugo Costa Paes and Simoneide Silva, for critical discussion and review of the paper, to Vera Lúcia Polez and Yanna Karla M Nóbrega, for technical assistance, and Dr Ana Joaquina Cohen and Professor Cleudson Nery de Castro, for establishing the liaison with PCM patients in Centre-Western Brazil.

\section{REFERENCES}

Balbi G, Ferrera F, Rizzi M, Piccioli P, Morabito A, Cardamone L, Ghio M, Palmisano GL, Carrara P, Pedemonte S, Sessarego M, De Angioletti M, Notaro R, Indiveri F, Pistillo MP 2007. Association of $-318 \mathrm{C} / \mathrm{T}$ and $+49 \mathrm{~A} / \mathrm{G}$ cytotoxic $\mathrm{T}$ lymphocyte antigen-4 (CTLA-4) gene polymorphisms with a clinical subset of Italian patients with systemic sclerosis. Clin Exp Immunol 149: 40-47. 
Barreto M, Santos E, Ferreira R, Fesel C, Fontes MF, Pereira C, Martins B, Andreia R, Viana JF, Crespo F, Vasconcelos C, Ferreira C, Vicente AM 2004. Evidence for CTLA4 as a susceptibility gene for systemic lupus erythematosus. Eur J Hum Genet 12: 620-626.

Barrett JC, Fry B, Maller J, Daly MJ 2005. Haploview: analysis and visualization of LD and haplotype maps. Bioinformatics 21: 263-265.

Blomhoff A, Lie BA, Myhre AG, Kemp EH, Weetman AP, Akselsen HE, Huseby ES, Undlien DE 2004. Polymorphisms in the cytotoxic T lymphocyte antigen-4 gene region confer susceptibility to Addison's disease. J Clin Endocrinol Metab 89: 3474-3476.

Bocca AL, Hayashi EE, Pinheiro AG, Furlanetto AB, Campanelli AP, Cunha FQ, Figueiredo F 1998. Treatment of Paracoccidioides brasiliensis-infected mice with a nitric oxide inhibitor prevents the failure of cell-mediated immune response. J Immunol 161: 3056-3063.

Bozzi A, Pereira PP, Reis BS, Goulart MI, Pereira MC, Pedroso EP, Leite MF, Goes AM 2006. Interleukin-10 and tumor necrosis factor-alpha single nucleotide gene polymorphism frequency in paracoccidioidomycosis. Hum Immunol 67: 931-939.

Bozzi A, Reis BS, Prado FL, Pedroso EP, Leite MF, Goes AM 2004. Modulation of CD28 and CD86 expression in patients with paracoccidioidomycosis in different periods of treatment. Scand J Immunol 60: 500-505.

Butty V, Roy M, Sabeti P, Besse W, Benoist C, Mathis D 2007. Signatures of strong population differentiation shape extended haplotypes across the human CD28, CTLA4 and ICOS costimulatory genes. Proc Natl Acad Sci USA 104: 570-575.

Campanelli AP, Martins GA, Souto JT, Pereira MS, Livonesi MC, Martinez R, Silva JS 2003. Fas-Fas ligand (CD95-CD95L) and cytotoxic $\mathrm{T}$ lymphocyte antigen- 4 engagement mediate $\mathrm{T}$ cell unresponsiveness in patients with paracoccidioidomycosis. $J$ Infect Dis 187: 1496-1505.

Carvalho A, Cunha C, Pasqualotto AC, Pitzurra L, Denning DW, Romani L 2010. Genetic variability of innate immunity impacts human susceptibility to fungal diseases. Int J Infect Dis 14: 460-468.

Cavassani KA, Campanelli AP, Moreira AP, Vancim JO, Vitali LH, Mamede RC, Martinez R, Silva JS 2006. Systemic and local characterization of regulatory $\mathrm{T}$ cells in a chronic fungal infection in humans. J Immunol 177: 5811-5818.

Dariavach P, Mattéi MG, Golstein P, Lefranc MP 1988. Human Ig superfamily CTLA-4 gene: chromosomal localization and identity of protein sequence between murine and human CTLA-4 cytoplasmic domains. Eur J Immunol 18: 1901-1905.

Deichmann K, Heinzmann A, Brüggenolte E, Forster J, Kuehr J 1996. An Mse I RFLP in the human CTLA-4 promotor. Biochem Biophys Res Commun 225: 817-818.

Franco M 1987. Host-parasite relationships in paracoccidioidomycosis. J Med Vet Mycol 25: 5-18.

Ghaderi A, Yeganeh F, Kalantari T, Talei AR, Pezeshki AM, Doroudchi M, Dehaghani AS 2004. Cytotoxic T lymphocyte antigen-4 gene in breast cancer. Breast Cancer Res Treat 86: 1-7.

Goldstein DB 2009. Common genetic variation and human traits. N Engl J Med 360: 1696-1698.

Gough SC, Walker LS, Sansom DM 2005. CTLA-4 gene polymorphism and autoimmunity. Immunol Rev 204: 102-115.

Guzman VB, Morgun A, Shulzhenko N, Mine KL, Gonçalves-Primo A, Musatti CC, Gerbase-Delima M 2005. Characterization of CD28, CTLA4 and ICOS polymorphisms in three Brazilian ethnic groups. Hum Immunol 66: 773-776.
Han S, Li Y, Mao Y, Xie Y 2005. Meta-analysis of the association of CTLA-4 exon-1 $+49 \mathrm{~A} / \mathrm{G}$ polymorphism with rheumatoid arthritis. Hum Genet 118: 123-132.

Harper K, Balzano C, Rouvier E, Mattéi MG, Luciani MF, Golstein P 1991. CTLA-4 and CD28 activated lymphocyte molecules are closely related in both mouse and human as to sequence, message expression, gene structure and chromosomal location. J Immunol 147: $1037-1044$.

Holopainen P, Naluai AT, Moodie S, Percopo S, Coto I, Clot F, Ascher H, Sollid L, Ciclitira P, Greco L, Clerget-Darpoux F, Partanen J, Members of the European Genetics Cluster on Coeliac Disease 2004. Candidate gene region 2q33 in European families with coeliac disease. Tissue Antigens 63: 212-222.

Kouki T, Sawai Y, Gardine CA, Fisfalen ME, Alegre ML, DeGroot LJ 2000. CTLA-4 gene polymorphism at position 49 in exon 1 reduces the inhibitory function of CTLA- 4 and contributes to the pathogenesis of Graves' disease. J Immunol 165: 6606-6611.

Kristiansen OP, Larsen ZM, Pociot F 2000. CTLA-4 in autoimmune diseases - a general susceptibility gene to autoimmunity? Genes Immun 1: 170-184.

Lee YH, Harley JB, Nath SK 2005. CTLA-4 polymorphisms and systemic lupus erythematosus (SLE): a meta-analysis. Hum Genet 116: 361-367.

Ligers A, Teleshova N, Masterman T, Huang WX, Hillert J 2001. CTLA-4 gene expression is influenced by promoter and exon 1 polymorphisms. Genes Immun 2: 145-152.

Ling V, Wu PW, Finnerty HF, Agostino MJ, Graham JR, Chen S, Jussiff JM, Fisk GJ, Miller CP, Collins M 2001. Assembly and annotation of human chromosome $2 \mathrm{q} 33$ sequence containing the $\mathrm{CD} 28$, CTLA4, and ICOS gene cluster: analysis by computational, comparative and microarray approaches. Genomics 78: 155-168.

Lins TC, Nogueira LR, Lima RM, Gentil P, Oliveira RJ, Pereira RW 2007. A multiplex single-base extension protocol for genotyping Cdx2, FokI, BsmI, ApaI and TaqI polymorphisms of the vitamin D receptor gene. Genet Mol Res 6: 316-324.

Lins TC, Vieira RG, Abreu BS, Grattapaglia D, Pereira RW 2010a. Genetic composition of Brazilian population samples based on a set of twenty-eight ancestry informative SNPs. Am J Hum Biol 22: $187-192$.

Lins TC, Vieira RG, Grattapaglia D, Pereira RW 2010b. Allele and haplotype frequency distribution in PTPN22 gene across variable ethnic groups: implications for genetic association studies for autoimmune diseases. Autoimmunity 43: 308-316.

Martins GA, Tadokoro CE, Silva RB, Silva JS, Rizzo LV 2004. CTLA-4 blockage increases resistance to infection with the intracellular protozoan Trypanosoma cruzi. J Immunol 172: 4893-4901.

Moreno Lima R, Silva de Abreu B, Gentil P, Cesar de Lima Lins T, Grattapaglia D, Pereira RW, Jacó de Oliveira R 2007. Lack of association between vitamin $\mathrm{D}$ receptor genotypes and haplotypes with fat-free mass in postmenopausal Brazilian women. J Gerontol A Biol Sci Med Sci 62: 966-972.

Nisticò L, Buzzetti R, Pritchard LE, Van der Auwera B, Giovannini C, Bosi E, Larrad MT, Rios MS, Chow CC, Cockram CS, Jacobs K, Mijovic C, Bain SC, Barnett AH, Vandewalle CL, Schuit F, Gorus FK, Tosi R, Pozzilli P, Todd JA 1996. The CTLA-4 gene region of chromosome $2 \mathrm{q} 33$ is linked to, and associated with, type 1 diabetes. Belgian Diabetes Registry. Hum Mol Genet 5: 1075-1080.

Pritchard JK, Stephens M, Donnelly P 2000. Inference of population structure using multilocus genotype data. Genetics 155: 945-959.

Restrepo A 1985. The ecology of Paracoccidioides brasiliensis: a puzzle still unsolved. Sabouraudia 23: 323-334. 
Rosenberg NA, Nordborg M 2006. A general population-genetic model for the production by population structure of spurious genotype-phenotype associations in discrete, admixed or spatially distributed populations. Genetics 173: 1665-1678.

Silva CL, Figueiredo F 1991. Tumor necrosis factor in paracoccidioidomycosis patients. J Infect Dis 164: 1033-1034.

Smith MW, Patterson N, Lautenberger JA, Truelove AL, McDonald GJ, Waliszewska A, Kessing BD, Malasky MJ, Scafe C, Le E, De Jager PL, Mignault AA, Yi Z, De The G, Essex M, Sankale JL, Moore JH, Poku K, Phair JP, Goedert JJ, Vlahov D, Williams SM, Tishkoff SA, Winkler CA, De La Vega FM, Woodage T, Sninsky JJ, Hafler DA, Altshuler D, Gilbert DA, O'Brien SJ, Reich D 2004. A high-density admixture map for disease gene discovery in African Americans. Am J Hum Genet 74: 1001-1013.

Su TH, Chang TY, Lee YJ, Chen CK, Liu HF, Chu CC, Lin M, Wang PT, Huang WC, Chen TC, Yang YC 2007. CTLA-4 gene and susceptibility to human papillomavirus-16-associated cervical squamous cell carcinoma in Taiwanese women. Carcinogenesis 28: $1237-1240$

Thio CL, Mosbruger TL, Kaslow RA, Karp CL, Strathdee SA, Vlahov D, O'Brien SJ, Astemborski J, Thomas DL 2004. Cytotoxic T-lymphocyte antigen 4 gene and recovery from hepatitis B virus infection. J Virol 78: 11258-11262.

Tomer Y, Greenberg DA, Barbesino G, Concepcion E, Davies TF 2001. CTLA-4 and not CD28 is a susceptibility gene for thyroid autoantibody production. J Clin Endocrinol Metab 86: 1687-1693.
Ueda H, Howson JM, Esposito L, Heward J, Snook H, Chamberlain G, Rainbow DB, Hunter KM, Smith AN, Di Genova G, Herr MH, Dahlman I, Payne F, Smyth D, Lowe C, Twells RC, Howlett S, Healy B, Nutland S, Rance HE, Everett V, Smink LJ, Lam AC, Cordell HJ, Walker NM, Bordin C, Hulme J, Motzo C, Cucca F, Hess JF, Metzker ML, Rogers J, Gregory S, Allahabadia A, Nithiyananthan R, Tuomilehto-Wolf E, Tuomilehto J, Bingley P, Gillespie KM, Undlien DE, Rønningen KS, Guja C, IonescuTîrgoviște C, Savage DA, Maxwell AP, Carson DJ, Patterson CC, Franklyn JA, Clayton DG, Peterson LB, Wicker LS, Todd JA, Gough SC 2003. Association of the T-cell regulatory gene CTLA-4 with susceptibility to autoimmune disease. Nature 423: 506-511.

van Belzen MJ, Mulder CJ, Zhernakova A, Pearson PL, Houwen RH, Wijmenga C 2004. CTLA4 $+49 \mathrm{~A} / \mathrm{G}$ and CT60 polymorphisms in Dutch coeliac disease patients. Eur J Hum Genet 12: 782-785.

Wang XB, Kakoulidou M, Giscombe R, Qiu Q, Huang D, Pirskanen R, Lefvert AK 2002. Abnormal expression of CTLA-4 by T cells from patients with myasthenia gravis: effect of an AT-rich gene sequence. J Neuroimmunol 130: 224-232.

Yanagawa T, Hidaka Y, Guimaraes V, Soliman M, DeGroot LJ 1995. CTLA-4 gene polymorphism associated with Graves' disease in a Caucasian population. J Clin Endocrinol Metab 80: 41-45.

Zaletel K, Krhin B, Gaberscek S, Hojker S 2006. Thyroid autoantibody production is influenced by exon 1 and promoter CTLA- 4 polymorphisms in patients with Hashimoto's thyroiditis. Int J Immunogenet 33: 87-91. 